\title{
FAKTOR DETERMINAN YIELD OBLIGASI PERUSAHAAN KORPORASI
}

\author{
Maunatun Zulfa* dan Aida Nahar \\ Universitas Islam Nahdlatul Ulama Jepara \\ *Email: Maunatunzulfaa@gmail.com
}

\begin{abstract}
DiPublikasi: 01/01/2020
http://dx.doi.org/10.22225/kr.11.2.1418.117-128

Abstract

The aims of this research was to analyze the effect of interest rates, bond ratings, company size, exchange rates, bond coupons, matutity, bond liquidity, solvency, and profitability on corporate bond yields. Yields have been received by investors from the bond investment profits are always fluctuating. The total number of population in this study were all corporate companies that issue bonds listed on the Indonesia Stock Exchange (IDX) for the 2015-2017 period. A total of 90 bonds from 12 corporate companies were sampled in this study. The analytical tool used is multiple linear regression. The results of this study indicate that the dominant factors affecting bond yields are bond coupons and maturity. Bond coupons have a positive and significant effect on bond yields. The result of the research showed that matutity could prove to produce a negative and significant effect on bond yields.
\end{abstract}

Keywords: Bond coupons; bond liquidity; bond ratings; bond yields; company size; exchange rates; interest rates; matutity; profitability; solvency

\begin{abstract}
Abstrak
Tujuan dari penelitian ini adalah untuk menganalisis pengaruh tingkat bunga, peringkat obligasi, ukuran perusahaan, nilai tukar, kupon obligasi, matutity, likuiditas obligasi, solvabilitas, dan profitabilitas terhadap hasil obligasi perusahaan. Imbal hasil yang diterima investor dari investasi obligasi selalu berfluktuasi. Jumlah total populasi dalam penelitian ini adalah semua perusahaan perusahaan yang menerbitkan obligasi yang terdaftar di Bursa Efek Indonesia (BEI) untuk periode 2015-2017. Sebanyak 90 obligasi dari 12 perusahaan perusahaan dijadikan sampel dalam penelitian ini. Alat analisis yang digunakan adalah regresi linier berganda. Hasil penelitian ini menunjukkan bahwa faktor dominan yang mempengaruhi hasil obligasi adalah kupon obligasi dan jatuh tempo. Kupon obligasi memiliki efek positif dan signifikan terhadap hasil obligasi. Hasil penelitian menunjukkan bahwa matutity dapat membuktikan menghasilkan efek negatif dan signifikan terhadap hasil obligasi.
\end{abstract}

Kata kunci: Kupon obligasi; likuiditas obligasi; peringkat obligasi; hasil obligasi; ukuran per usahaan; nilai tukar; suku bunga; matutity; keuntungan; solvabilitas

\section{PENDAhuluan}

Pasar modal merupakan pasar jangka panjang yang didalamnya terdapat berbagai macam instrumen pasar modal yang dapat diperjualbelikan (Aisah, 2014). Disisi lain pasar modal juga mempertemukan antara pihak yang membutuhkan dana dan pihak yang memerlukan dana jangka panjang. Para investor disediakan dengan berbagai macam alternatif untuk dikembangkan dan dikelola untuk jangka waktu yang panjang dengan tujuan mendapatkan imbalan sesuai dengan yang diharapkan.

Dalam pasar modal terdapat lembaga pemerintah yang berperan sebagai penyelenggara bursa dan memfasilitasi perdagangan efek Indonesia yaitu Bursa Efek Indonesia (BEI)
(Nasuha, 2018). Bursa Efek Indonesia (BEI) biasanya mengontrol proses transaksi efek di Indonesia agar berjalan dengan adil dan efisien serta sebagai media untuk perusahaan yang ingin go public. Dengan adanya BEI sebagai penyelenggara bursa, menjadi salah satu alasan berinvestasi di Indonesia dengan aman. Hal ini karena BEI memiliki kewenangan terhadap para anggota bursa dan emiten yang tercatat.

Produk yang diperdagangkan dalam bursa efek yaitu terdiri dari saham, obligasi dan surat pernyataan utang lainnya (Nuary, 2015). Saham adalah surat berharga sebagai tanda kepemilikan terhadap suatu perusahaan. Sedangkan obligasi merupakan bukti utang dari emiten (penawar) yang dijamin oleh penanggung yang mengandung janji pelunasan pokok pinjaman dan pembayaran 
bunga yang dilakukan pada tanggal jatuh tempo (Aisah, 2014). Pada umumnya investor yang tidak ingin mengambil risiko yang besar, lebih memilih investasi pada obligasi karena keamanan modal yang berkualitas tinggi, obligasi juga memberikan hasil (return) tetap selama periode jangka waktu yang relatif panjang dan tidak terpengaruh terhadap fluktuasi tingkat bunga.

Berdasarkan data statistik Pasar Modal Indonesia yang diolah oleh Otoritas Jasa Keuangan (OJK), terjadi peningkatan perdagangan obligasi korporasi pada tahun 2015 sampai tahun 2017.

Tabel 1

Indonesia Bond Indexes

\begin{tabular}{cccc}
\hline Periode & \multicolumn{3}{c}{ INDOBex Total Return } \\
\cline { 2 - 4 } 2015 & Composite & Government & Corporate \\
2016 & 183.2792 & 180.3796 & 196.5327 \\
2017 & 208.4493 & 205.5032 & 221.2946 \\
\hline
\end{tabular}

Sumber: Otoritas Jasa Keuangan (OJK), 2017

Berdasarkan tabel tersebut terdapat fenomena yang mengindikasikan bahwa obligasi korporasi mulai banyak diminati dan mulai marak diperdagangkan di Pasar Modal Indonesia. Meskipun demikian, investasi obligasi juga memiliki risiko yang akan dihadapi oleh investor. Risiko yang terdapat pada obligasi akan mempengaruhi tingkat return yang diharapkan oleh investor yang dikenal dengan yield obligasi. Pendapatan atau imbal hasil (return) yang akan diterima investor dari hasil penempatan dananya pada obligasi dinamakan yield (Aisah, 2014). Sebagai instrumen investasi, perubahan tingkat imbal hasil (yield) obligasi yang diperoleh investor mengalami perubahan seiring dengan berjalannya waktu, perubahan yield tersebut berpengaruh pada tingkat harga pasar obligasi itu sendiri. Oleh karena itu, investor dan emiten harus selalu memperhatikan fluktuasi harga obligasi dan faktor-faktor yang mempengaruhi perubahan yield obligasi.

Faktor suku bunga sangat berpengaruh terhadap naik turunnya yield obligasi seperti hasil penelitian yang dilakukan oleh Nuray (2015), Kurniasari (2016) dan Laras (2018) yang menujukkan pengaruh positif terhadap yield obligasi. Perubahan suku bunga akan mempengaruhi nilai obligasi, dimana dampak harga obligasi, yakni perubahan harga obligasi ketika suku bunga mengalami perubahan. Ketika suku bunga mengalami kenaikan, emiten obligasi akan menawarkan yield yang lebih tinggi, sehingga harga obligasi di pasar akan menyesuaikan, yakni menurun, sebaliknya pada saat suku bunga mengalami penurunan maka harga obligasi dipasar akan mengalami peningkatan.
Faktor lain yang dapat mempengaruhi yield obligasi yaitu peringkat obligasi merupakan salah satu faktor yang mempengaruhi yield obligasi (Kurniasari, 2016). Peringkat obligasi merupakan faktor utama untuk menilai apakah perusahaan tersebut layak atau tidak dalam menerbitkan obligasi, sehingga investor tidak ragu dalam menginvestasikan dananya. Besar kecilnya perusahaan juga dapat berpengaruh pada penerbitan obligasi. Menurut penelitian yang dilakukan oleh Oky dan Nuray (2015) menunjukkan hasil bahwa peringkat obligasi berpengaruh positif terhadap yield obligasi. Lain halnya dengan penelitian Neneng (2017) yang mengatakan bahwa peringkat obligasi tadak berpengaruh terhadap yield obligasi.

Investor dan kreditor harus memperhatikan karakteristik keuangan dalam setiap perusahaan. Ukuran (size) perusahaan dapat mewakili karakteristik keuangan perusahaan (Desnitasari, 2013). Perusahaan skala besar lebih mudah dalam mendapatkan dana dari berbagai sumber, salah satunya pinjaman dari kreditur karena perusahaan dengan ukuran besar memiliki probabilitas lebih besar untuk memenangkan persaingan atau bertahan dalam industri. Menurut hasil penelitian Mutiarany (2015) dan Siti (2014) terdapat pengaruh negatif antara ukuran perusahaan terhadap yield obligasi.

Dalam pengukuran yield obligasi nilai tukar juga dapat mempengaruhi besarnya nilai obligasi. Nilai tukar atau kurs merupakan harga mata uang lokal yang bisa dipergunakan untuk membeli mata uang lainnya (Muhardi, 2013). Di Indonesia nilai tukar uang akan berubah sesuai dengan permintaan dan penawaran. Hal ini dikarenakan menganut sistem bebas mengambang (floating 
(Studi Empiris Pada Pemerintah Kabupaten Badung)

exchange rate). Menurut Kurniasari (2016) terdapat pengaruh negatif antara nilai tukar terhadap yield obligasi.

Besarnya yield obligasi dapat diukur dari banyaknya kepemilikan kupon obligasi. Kupon obligasi merupkan pendapatan suku bunga yang diterima oleh pemegang obligasi atas perjanjian dengan penerbit obligasi (Hidayat, 2016). Kupon yang tinggi akan menjadikan obligasi menarik bagi investor karena nilainya yang tinggi akan memberikan yield yang makin tinggi pula. Menurut hasil penelitian dari Neneng (2017) menunjukkan adanya pengaruh positif antara kupon terhadap yield obligasi.

Sebelum obligasi ditransaksikan, pihak-pihak yang terkait harus menyetujui nilai yang dijanjikan perusahaan yang akan dibayarkan pada saat jatuh tempo dengan membayar pokok dan bunga kepada pembeli obligasi, hal tersebut dinamakan maturity obligasi (Hartono, 2013). Salah satu karakteristik yang akan dipertimbangkan oleh investor sebelum menginvestasikan dananya adalah maturitas obligasi. Menurut hasil penelitian dari Neneng (2017) menunjukkan pengaruh yang negatif antara maturitas dengan yield obligasi.

Investor dalam menginvestasikan dananya terdapat beberapa pertimbangan, salah satunya yaitu likuiditas dari suatu obligasi menunjukkan seberapa cepat investor dapat menjual obligasinya tanpa mengorbankan harga obligasinya. Salah satu pengukuran dari likuiditas obligasi yaitu tentang permintaan dan penawaran yang menunjukkan perbedaan antara antara permintaan tertinggi investor mau menjual dan penawaran terendah dealer mau membeli (Hartono, 2013). Menurut hasil penelitian yang dilakukan oleh Neneng (2017) menunjukkan pengaruh yang negatif antara likuiditas dengan yield obligasi. Likuiditas obligasi yang tinggi akan menjadikan obligasi lebih menarik karena tersedianya penjual dan pembeli obligasi yang banyak, sehingga akan mudah dalam pemperjualbelikan. (Hartono, 2013)

Dalam menilai suatu prestasi manajemen terhadap pengelolaan perusahaan yaitu menggunakan analisis rasio. Rasio keuangan sangat penting dalam melakukan analisis terhadap kondisi keuangan perusahaan. Dalam penelitian ini menggunakan analisis rasio solvabilitas dan rentabilitas. Solvabilitas adalah tersedianya dana dalam jumlah tertentu untuk kelangsungan kegiatan operasi perusahaan (Kasmir, 2013). Rentabilitas adalah kemampuan perusahaan untuk menghasilkan keuntungan dengan menggunakan modal yang tertanam didalamnya (Kasmir, 2013). Apabila yang dingunakan adalah seluruh modal yang tertanam didalamnya, dalam hal ini seluruh aktiva atau kekayaan milik perusahaan.

Menurut penelitian yang dilakukan oleh Neneng (2017) menunjukkan hasil bahwa solvabilitas berpengaruh positif terhadap yield obligasi. Lain halnya dengan penelitian Oky (2015) dan Laras (2018) yang mengatakan bahwa solvabilitas tidak berpengaruh yield obligasi. Dari kesimpulan hasil penelitian terdahulu menunjukkan bahwa masih terdapat research gap mengenai penelitian analisis faktor-faktor yang mempengaruhi yield obligasi, sehingga peneliti tertarik untuk melakukan penelitian mengenai "Analisis Faktor Determinasi Yield Obligasi Pada Perusahaan Korporasi Yang Terdaftar Di Bursa Efek Indonesia (BEI) Periode 20152017". Penelitian ini dilakukan untuk menganalisis pengaruh suku bunga, Peringkat, Ukuran Perusahaan, Nilai Tukar, Kupon, Maturity, Likuiditas, Solvabilitas, dan Rentabilitas terhadap yield obligasi periode 20152017.

\section{LITERATUR REVIEW DAN HIPOTESIS}

\section{Yield Obligasi}

Pendapatan atau imbalan hasil atau return yang akan diperoleh dari investasi obligasi dinyatakan sebagai yield, yaitu hasil yang akan diperoleh investor apabila menempatkan dananya untuk dibelikan obligasi (Susilo, 2009). Sebelum memutuskan untuk berinvestasi obligasi, investor harus mempertimbangkan besarnya yield obligasi, sehingga diketahui adanya yield yang diharapkan oleh investor.

\section{Suku Bunga}

Tingkat suku bunga adalah tingkat bunga dinyatakan dalam persen yang akan dibayar peminjam (debitur) kepada pihak yang meminjamkan (kreditur) atas pemakaian sumber daya dengan jangka waktu tertentu (perbulan atau pertahun) (Desnitasari, 2013). Pada besarnya tingkat suku bunga mempunyai pengaruh yang positif terhadap yield obligasi, dikarenakan apabila terjadi kenaikan tingkat suku bunga maka yield obligasi juga akan meningkat. Menurut penelitian yang dilakukan oleh Saputra (2013) telah membuktikan bahwa suku bunga dengan yield obligasi mempunyai pengaruh yang positif 
dan signifikan. Karena apabila tingkat suku bunga naik maka tingkat keuntungan yang diisyaratkan oleh investor atau yield obligasi juga akan mengalami kenaikan, atau berkorelasi positif.

Berdasarkan uraian diatas, hipotesis dalam penelitian yaitu:

H1 : Tingkat suku bunga berpengaruh positif dan signifikan terhadap yield obligasi.

\section{Peringkat Obligasi}

Peringkat obligasi adalah proses untuk menentukan tingkat risiko gagal bayar yang melekat pada perusahaan yang akan menerbitkan obligasi (Prihadi, 2010). Dalam investasi obligasi yang berperingkat tinggi akan menawarkan yield obligasi yang rendah, dan sebaliknya jika obligasi berperingkat rendah maka akan menawarkan yield obligasi yang tinggi. Hal ini menunjukkan bahwa peringkat obligasi memiliki pengaruh negatif terhadap yield obligasi. Penelitian yang dilakukan oleh Oky (2015) dan Neneng (2017) telah membuktikan bahwa terdapat pengaruh negatif dan signifikan antara peringkat obligasi terhadap yield obligasi.

Berdasarkan uraian diatas, hipotesis dalam penelitian yaitu:

$\mathrm{H} 2$ : Peringkat obligasi berpengaruh negatif dan signifikan terhadap yield obligasi.

\section{Ukuran Perusahaan}

Ukuran perusahaan adalah suatu skala dimana dapat diklasifikasikan besar kecilnya perusahaan menurut berbagai cara, antara lain: total aktiva, log size, nilai pasar saham, dan lain-lain (Paramita, 2018). Pada umumnya ukuran perusahaan tidak berpengarauh terhadap yield obligasi, karena jika investor berani dalam mengambil risiko sebaiknya berinvestasi pada obligasi yang dijual atau diterbitkan oleh perusahaan yang berskala kecil karena akan menawarkan yield obligasi yang besar. Sedangkan bagi investor yang lebih mengutamakan dalam pencegahan risiko, maka sebaliknya berinvestasi pada obligasi yang dijual atau diterbitkan oleh perusahaan yang berskala besar dengan yield yang lebih rendah tetapi memiliki tingkat keamanan yang lebih besar.

Dalam penelitian yang dilakukan oleh Desnitasari (2013) telah membuktikan bahwa terdapat pengaruh negatif dan signifikan antara ukuran perusahaan terhadap yield obligasi.

Berdasarkan uraian diatas, hipotesis dalam penelitian yaitu:

H3 : Ukuran perusahaan berpengaruh negatif dan signifikan terhadap yield obligasi.

\section{Nilai Tukar}

Kurs atau nilai tukar adalah harga suatu mata uang yang dapat ditukarkan dengan satu mata uang lainnya (Muhardi, 2013). Dampak dari perubahan nilai tukar akan menyebabkan terjadinya panguatan atau pelemahan mata uang suatu negara. Kurs yang positif akan membuat nilai perusahaan akan mengalami kenaikan sehingga terjadi peningkatan harga sekuritas seperti obligasi. Hal tersebut akan berpengaruh terhadap yield obligasi, karena jika nilai tukar naik akan berpengaruh positif terhadap harga obligasi yang menyebabkan yield obligasi akan menurun.

Menurut hasil penelitian yang dilakukan oleh Kurniasari (2016) telah membuktikan bahwa terdapat pengaruh negatif dan signifikan antara nilai kurs terhadap yield obligasi.

Berdasarkan uraian diatas, hipotesis dalam penelitian yaitu:

H4 : Nilai tukar berpengaruh negatif dan signifikan terhadap yield obligasi.

\section{Kupon Obligasi}

Kupon obligasi adalah pendapatan bunga yang dibayarkan kepada pemegang obligasi atas perjanjian dengan penerbit obligasi untuk setiap periode tertentu, pada umumnya tiap setengah tahun atau tahunan (Hartono, 2013). Apabila kupon obligasi tersebut cukup tinggi maka yield obligasi semakin tinggi pula, sehingga permintaan obligasi akan semakin meningkat. Adanya permintaan obligasi yang tinggi dan dengan penawaran yang tetap akan membuat harga obligasi naik. Dengan demikian dapat dikatakan bahwa kupon obligasi berpengaruh positif terhadap yield obligasi.

Dalam penelitian yang dilakukan oleh Permana (2017) telah membuktikan bahwa terdapat pengaruh positif dan signifikan antara kupon obligasi terhadap yield obligasi.

Berdasarkan uraian diatas, hipotesis dalam penelitian yaitu:

H5 : Kupon obligasi berpengaruh positif dan signifikan terhadap yield obligasi.

\section{Maturity Obligasi}

Maturitas atau maturity date yaitu tanggal 
dimana nilai yang dijanjikanakan dibayar pada saat jatuh tempo (Hartono, 2013). Salah satu faktor yang dapat mempengaruhi fluktuasi harga obligasi adalah tingkat maturitas, yaitu periode jatuh tempo untuk melunasi seluruh pinjaman yang telah disepakati. Secara umum, semakin lama tingkat maturitas sebuah obligasi maka semakin besar tingkat resikonya sehingga, yield obligasi yang ditawarkan akan semakin besar pula. Dan sebaliknya apabila semakin lama waktu jatuh tempo suatu obligasi maka semakin besar tingkat ketidakpastian yang harus dihadapi investor obligasi dan sebaliknya, jika semakin pendek jangka waktu jatuh tempo dari sebuah obligasi maka semakin kecil juga tingkat risiko atau ketidakpastian yang akan diterima oleh investor.

Dalam penelitian yang dilakukan oleh Andrian (2011) telah membuktikan bahwa terdapat pengaruh positif antara maturitas terhadap yield obligasi.

Berdasarkan uraian diatas, hipotesis dalam penelitian yaitu:

H6 : Maturity berpengaruh positif dan signifikan terhadap yield obligasi.

\section{Likuiditas Obligasi}

Obligasi yang likuid adalah obligasi yang banyak beredar di kalangan pemegang obligasi serta sering diperdagangkan oleh investor di pasar obligasi (Indarsih, 2013). Likuiditas obligasi yang tinggi akan menyebabkan obligasi lebih menarik karena tersedianya pembeli dan penjual yang lebih banyak sehingga obligasi dapat diperjual belikan kapan saja. Dengan likuditas obligasi yang tinggi akan membuat harga obligasi cenderung stabil dan meningkat, sehingga menyebabkan yield obligasi menurun karena tingkat risiko lebih rendah.

Dalam penelitian yang dilakukan oleh Oktavian (2015) dan Paramita (2018) telah membuktikan bahwa terdapat pengaruh negatif antara likuiditas obligasi terhadap yield obligasi. Berdasarkan uraian diatas, hipotesis dalam penelitian yaitu:

H7 : Likuiditas obligasi berpengaruh negatif dan signifikan terhadap yield obligasi.

\section{Solvabilitas}

Solvabilitas atau Leverage merupakan rasio keuangan yang menunjukkan proporsi penggunaan utang untuk membiayai investasi terhadap modal yang dimiliki (Kasmir, 2013). Rasio ini digunakan untuk mengukur sejauh mana perusahaan menggunakan utang sebagai sumber dananya. Salah satu alat yang dipakai untuk mengukur rasio solvabilitas adalah dengan menggunakan debt to equity ratio. Perusahaan besar yang memiliki debt to equity ratio tinggi akan menawarkan yield yang rendah dan begitu pula sebaliknya, apabila perusahaan yang memiliki skala kecil memiliki debt to equity ratio yang rendah sehingga menawarkan yield tinggi untuk menarik investor berinvestasi pada obligasi yang diterbitkannya. Hal ini menunjukkan bahwa dalam berinvestasi investor tidak harus memerhatikan debt to equity ratio suatu perusahaan, dan investor menganggap bahwa perusahaan yang menerbitkan obligasi sudah go public sehingga investor tidak terlalu khawatir dengan risiko tersebut.

Dalam penelitian yang dilakukan oleh Oky (2015) dan Laras (2018) telah membuktikan bahwa terdapat pengaruh negatif dan signifikan antara solvabilitas terhadap yield obligasi. Berdasarkan uraian diatas, hipotesis dalam penelitian yaitu:

H8 : Solvabilitas berpengaruh negatif dan signifikan terhadap yield obligasi.

\section{Rentabilitas}

Rentabilitas adalah rasio yang mengukur kemampuan perusahaan menghasilkan keuntungan (profit) (Kasmir, 2013). Perusahaan dengan profit tinggi akan menyebabkan risiko ketidakmampuan membayar (default) menjadi lebih rendah, sehingga yield yang ditawarkan menjadi lebih rendah pula. Untuk mengukur rasio rentabilitas pada penelitian ini menggunakan rasio Return On Total Asset (ROA) yang menunjukkan bahwa semakin besar rasio ini mengidentifikasikan kecilnya yield yang akan diberikan kepada investor.

Dalam penelitian yang dilakukan oleh (Faizah dkk, 2013) telah membuktikan bahwa terdapat pengaruh negatif antara rentabilitas terhadap yield obligasi.

Berdasarkan uraian diatas, hipotesis dalam penelitian yaitu:

H9 : Terdapat pengaruh negatif dan signifikan antara rentabilitas terhadap yield obligasi.

\section{III.METODE}


(Studi Empiris Pada Pemerintah Kabupaten Badung)

\section{Populasi dan Sampel}

Populasi dalam penelitian ini adalah seluruh perusahaan korporasi yang aktif menerbitkan obligasi yang diperdagangkan dan telah terdaftar di Bursa Efek Indonesia (BEI) pada periode 2014 -2017 atau 3 tahun pengamatan dengan sampel 12 perusahaan yang menerbitkan obligasi dengan jumlah obligasi sebanyak 90 jenis obligasi. Dalam pengambilan sampel penelitian menggunakan metode sampel jenuh atau sensus, yaitu teknik penentuan sampel bila semua anggota populasi digunakan sebagai sampel (Sugiono, 2014).

\section{Variabel Penelitian}

\section{Yield Obligasi}

Yield obligasi adalah pendapatan atau imbalan hasil yang akan diperoleh investor apabila menempatkan dananya untuk dibelikan obligasi hingga jatuh tempo (Susilo, 2009).

Rumus untuk menghitung Yield to maturity (YTM) adalah: (Tandelilin, 2010).

$$
Y T M=\frac{C_{i}+\frac{P_{p}-P}{n}}{\frac{P_{p}+P}{2}}
$$

Keterangan:

YTM = Nilai Y ield to maturity

$\mathrm{Ci}=$ Pembayaran kupon untuk obligasi $\mathrm{i}$ setiap tahunnya

$\mathrm{P} \quad=$ Harga obligasi pada saat ini

$\mathrm{P}_{\mathrm{P}} \quad=$ Nilai par dari obligasi / nilai nominal

$\mathrm{n}$ = Jumlah tahun sampai dengan jatuh tempo obligasi

\section{Tingkat Suku Bunga}

Tingkat suku bunga adalah tingkat bunga dinyatakan dalam persen yang akan dibayar peminjam (debitur) kepada pihak yang meminjamkan (kreditur) atas pemakaian sumber daya dengan jangka waktu tertentu (perbulan atau pertahun) (Desnitasari, 2013).

Rumus untuk menghitung suku bunga adalah sebagai berikut:

$$
\text { I Rate }=\text { Tingkat Suku Bunga SBI }
$$

(Hartono, 2013)

\section{Peringkat Obligasi}

Peringkat obligasi merupakan pernyataan dalam bentuk simbol tentang keadaan perusahaan penerbit obligasi yang di keluarkan oleh PT Pefindo (pemeringkat efek indonesia) (pefindo.com).

Tabel 2

Klasifikasi level pemeringkat obligasi

\begin{tabular}{cc}
\hline Peringkat Obligasi & Klasifikasi \\
\hline idAAA & 4 \\
idAA+ & 3 \\
Idea & 3 \\
idAA- 3 & 3 \\
idA+2 & 2 \\
idA 2 & 2 \\
idA- 2 & 2 \\
idBBB+ 1 & 1 \\
idBBB 1 & 1 \\
idBBB- & 1 \\
\hline
\end{tabular}

Sumber : PT. Pefindo, (2019)

\section{Ukuran Perusahaan}

Ukuran perusahaan merupakan total kekayaan (total asset) yang dimiliki oleh suatu perusahaan (Permana, 2017). Untuk menghitung ukuran perusahaan dapat dengan rumus sebagai berikut:

$$
\text { Ukuran Perusahaan }=\text { Total Aset }
$$

(Fahrizqi, 2010)

\section{Nilai Tukar}

Nilai tukar adalah mata uang suatu negara yang dapat ditukarkan dengan mata uang negara lainnya (Husnan, 2005). Dalam menghitung nilai tukar suatu negara dapat menggunakan rumus sebagai berikut:

Kurs Tengah $=\underline{\text { kurs jual }+ \text { kurs beli } \quad 2}$

(Husnan, 2005)

\section{Kupon Obligasi}

Kupon obligasi adalah pendapatan bunga yang dibayarkan kepada pemegang obligasi atas perjanjian dengan penerbit obligasi untuk setiap periode tertentu (Hartono, 2013). Kupon obligasi diukur dengan menggunakan kupon yang diberikan oleh emiten obligasi dengan rumus sebagai berikut: 
Tingkat Kupon $=\underline{\text { Tingkat bunga tahunan }}$

Nilai nominal

(Tandelilin, 2010)

\section{Maturity Obligasi}

Maturity obligasi adalah periode waktu awal investasi obligasi sampai jatuh tempo obligasi (Hartono, 2013) Dalam mengukur maturitas obligasi dihitung menggunakan rumus sebagai berikut:

$$
\text { Maturity }=\text { Jangka waktu jatuh tempo }
$$

(Rozali, 2017)

\section{Likuiditas Obligasi}

Likuiditas obligasi adalah kecepatan atau seberapa sering obligasi diperdagangkan di Bursa Efek Indonesia (BEI) (Hartono, 2013). Dalam mengukur likuiditas obligasi yaitu menggunakan frekuensi perdagangan obligasi selama periode pengamatan.

\section{Solvabilitas}

Rasio solvabilitas adalah menunjukkan sejauh mana perusahaan menggunakan utang dalam membiayai investasinya (Kasmir, 2013). Dalam menghitung rasio solvabilitas yang diukur dengan menggunakan rasio debt to equity ratio dengan rumus sebagai berikut:

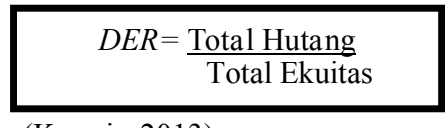

(Kasmir, 2013)

\section{Rentabilitas}

Rasio rentabilitas adalah menunjukkan kemampuan perusahaan dalam menghasilkan laba (Kasmir, 2013). Dalam menghitung rasio rentabilitas diukur dengan menggunakan rasio ROA dengan rumus sebagai berikut:

$$
\text { ROA }=\frac{\text { Laba Bersih }}{\text { Total Aktiva }}
$$

(Kasmir, 2013)

\section{Metode Pengumpulan Data}

Data yang diambil dari penelitian ini adalah data sekunder. Data sekunder merupakan sumber data yang diperoleh peneliti secara tidak langsung melalui media perantara dan pada umumnya berupa bukti, catatan atau historis yang telah tersusun dalam arsip yang dipublikasikan dan tidak di publikasikan (Indriantoro, 2000). Data dalam penelitian ini bersumber dari Indonesia Stock Exchange (IDX) dan Indonesia Bond Pricing Agency (IBPA), IDN Fiancial, dan PT. Pefindo selama periode penelitian.

\section{Metode Analisis Data}

\section{Analisis Deskriptif}

Analisis ini digunakan untuk mengetahui deskripsi dan perbedaan setiap variabel penelitian maka diperlukan statistik deskriptif yang akan menunjukkan distribusi sampel. Statistik deskriptif menyajikan data-data numerik meliputi nilai minimum, nilai maximum, nilai rat-rata (mean), dan standar deviasi. Berikut adalah hasil standar deviasi yang telah diolah menggunakan IBM SPSS 23

Berdasarkan data statistik deskriptif pada tabel 2 dengan distribusi sampel 90 dari data tahunan dimulai tahun 2015-2017, terlihat bahwa Yield to Maturity (YTM) merupakan imbalan hasil dari investasi obligasi yang dipegang sampai saat jatuh tempo. Berdasarkan tabel statistik deskriptif diatas, yield to maturity obligasi memiliki nilai minimum sebesar 9,52 pada obligasi berkelanjutan II Indosat Tahap II Tahun 2017 Seri D, nilai maximum sebesar 14,13 pada obligasi berkelanjutan II Medco Energi Internasional Tahap I Tahun 2016 Seri A dan nilai rata-rata atau mean sebesar 11,8101 dengan standar deviasi sebesar 1,21488. Hal ini menunjukkan bahwa data variabel yield to maturity sudah baik dan terdistribusi secara normal, karena nilai rataratanya lebih besar dibanding nilai standar deviasi yang dimiliki oleh yield to maturity.

Suku Bunga merupakan tingkat bunga dinyatakan dalam persen yang akan diterima oleh pemilik dari pihak peminjam dana. Berdasarkan tabel statistik deskriptif diatas, suku bunga memiliki nilai minimum sebesar 4,25 pada tahun 2017, nilai maximum sebesar 7,15 pada tahun 2015, nilai rata-rata atau mean sebesar 4,9867 dengan standar deviasi sebesar 1,07384. Nilai standar deviasi tersebut menunjukkan tidak ada kesenjangan yang cukup besar pada variabel suku bunga SBI dari tahun 2015-2017.

Rating obligasi merupakan pernyataan dalam bentuk simbol tentang keadaan penerbit obligasi yang dikeluarkan oleh Pefindo. Berdasarkan tabel statistik deskriptif diatas, tingkat rating memiliki 
nilai minimum sebesar 1,0 , nilai maximum sebesar 4,0. Nilai terendah dan tertinggi tersebut diperoleh dari skala yang menggambarkan peringkat tinggi rendahnya suatu obligasi. Skala tersebut ditentukan dari angka 1 hingga 4 untuk obligasi yang memiliki peringkat AAA hingga BBB- dalam kategori investasi yang layak. Nilai rata-rata atau mean sebesar 3,122 dan nilai standar deviasi sebesar 1,0037 yang menunjukkan bahwa 90 jenis obligasi yang diteliti tidak memiliki kesenjangan peringkat yang cukup besar.

Ukuran Perusahaan adalah suatu skala yang diklasifikasikan pada besar kecilnya perusahaan. Berdasarkan tabel statistik deskriptif diatas, ukuran perusahaan memiliki nilai minimum sebesar 8.215.481 pada obligasi berkelanjutan I Thipone Tahun 2016, nilai maximum sebesar 5.160.785.857 pada obligasi berkelanjutan II Medco Energi Internasional Tahun 2017, nilai rata-rata atau mean sebesar 898.641.147,41 dengan standar deviasi sebesar 1.576.877.137,371.

Nilai Tukar adalah suatu mata uang negara yang dapat ditukarkan dengan mata uang negara lainnya. Berdasarkan tabel statistik deskriptif diatas, nilai tukar memiliki nilai minimum sebesar 9.724,310 terjadi pada nilai tukar tahun 2016, nilai maximum sebesar $10.557,285$ terjadi pada nilai tukar tahun 2017, nilai rata-rata atau mean sebesar 10.145,68361 dengan standar deviasi sebesar 381,127839.

Kupon merupakan pendapatan bunga yang dibayarkan kepada pemegang obligasi atas perjanjian dengan penerbit obligasi untuk setiap periode tertentu. Berdasarkan tabel statistik deskriptif diatas, tingkat inflasi memiliki nilai minimum sebesar 6,75 pada obligasi berkelanjutan IV Adira Finance Tahap I Tahun 2017 Seri B, nilai maximum sebesar 11,30 pada obligasi berkelanjutan II Medco Energi Internasional Tahap IV Th 2017 Seri B, nilai ratarata atau mean sebesar 9,3646 dengan standar deviasi sebesar 1,16003.

Maturity adalah periode jatuh tempo untuk melunasi seluruh pinjaman yang telah disepakati. Berdasarkan tabel statistik deskriptif diatas, maturity obligasi memiliki nilai minimum sebesar 2,0 pada perusahaan yang memiliki obligasi yang memiliki jatuh tempo 2 tahun, nilai maximum sebesar 10,0. Hasil tersebut menunjukkan bahwa besarnya Jangka Waktu Jatuh Tempo yang menjadi sampel penelitian ini berkisaran 2 dan
10, dengan nilai rata-rata atau mean sebesar 4,911 dengan standar deviasi sebesar 2,1445. Nilai Jangka Waktu Jatuh Tempo tertinggi dicapai oleh obligasi berkelanjutan II Bank BRI Tahap II Th 2017 Seri D dan obligasi berkelanjutan II IndosatTahap II Th 2017 Seri E, sedangkan nilai jangka waktu jatuh tempo terendah dialami pada obligasi berkelanjutan IV Adira Finance Tahap Tahun 2017 Seri B dan obligasi berkelanjutan II Bank OCBC NISP Tahap III Tahap 2017 Seri B.

Likuiditas Obligasi adalah kecepatan atau seberapa sering obligasi diperdagangkan di Bursa Efek Indonesia (BEI). Berdasarkan tabel statistik deskriptif diatas, likuiditas obligasi memiliki nilai minimum sebesar 1,0 pada obligasi yang beredar satu kali dalam satu tahunnya, nilai maximum sebesar 2,0 pada obligasi yang beredar dua kali dalam satu tahun, nilai rata-rata atau mean sebesar 1,272 dengan standar deviasi sebesar 0,4504 .

Solvabilitas adalah menunjukkan sejauh mana perusahaan menggunakan utang dalam membiayai investasinya. Berdasarkan tabel statistik deskriptif diatas, solvabilitas memiliki nilai minimum sebesar 0,93 menunjukkan bahwa setiap Rp 1 aset dibiayai oleh utang sebesar Rp 0,93 . Nilai minimal tersebut dimiliki perusahaan Sarana Multygriya Finansial Tahun 2016. Nilai maximum sebesar 11,40 menunjukkan bahwa setiap Rp 1 aset dibiayai oleh utang sebesar Rp 11,40 pada obligasi berkelanjutan II Medco Energi Internasional Tahun 2017. Selama tahun 2015-2017 menunjukkan rata-rata atau mean tingkat solvabilitas perusahaan manufaktur yang terdaftar di BEI sebesar 4,3938 dengan standar deviasi sebesar 2,55622.

Rentabilitas adalah satu ukuran keberhasilan finansial yang dapat dicapai perusahaan pada suatu periode. Berdasarkan tabel statistik deskriptif diatas, rentabilitas memiliki nilai minimum sebesar $-0,02$ pada obligasi obligasi berkelanjutan I IndosatTahap III Th 2015, nilai maximum sebesar 0,06 pada obligasi berkelanjutan I Thipone Tahap II Th 2016 Seri C, nilai rata-rata atau mean sebesar 0,0274 dengan standar deviasi sebesar 0,01864.

Sebelum melakukan pengujian hipotesis perlu dilakukan uji prasyarat yaitu uji asumsi klasik. Uji asumsi klasik meliputi uji normalitas data, uji multikolonieritas, uji heterokedastisitas, dan uji autokorelasi. Berdasarkan hasil uji asumsi klasik, terlihat bahwa model penelitian ini sudah berdistribusi normal, tidak ada multikolonieritas 
antar variabel independen dalam model regresi, model regresi tidak terdeteksi adanya Heteroskedastisitas serta tidak terdeteksi autokorelasi.

Nilai koefisien determinasi (Adjusted $R$ Squere) sebesar 0,932. Hal ini berarti besar variasi variabel yield obligasi pada perusahaan korporasi dapat diterangkan oleh variabel suku bunga, peringkat, ukuran perusahaan, nilai tukar, kupon, maturitas, likuiditas obligasi, solvabilitas, dan rentabilitas adalah sebesar 93,2\% sedangkan sisanya $6,8 \%$ dipengaruhi oleh variabel lain diluar model penelitian.

Tabel 2

Statistik Deskriptif

\begin{tabular}{cccccc}
\hline \multicolumn{5}{c}{ Descriptive Statistics } \\
\hline N & Minimum & Maximum & Mean & Std. Deviation \\
YTM & 90 & 9,52 & 14,13 & 11,8101 & 1,21488 \\
Suku Bunga & 90 & 4,25 & 7,15 & 4,9867 & 1,07384 \\
Rating & 90 & 1,0 & 4,0 & 3,122 & 1,0037 \\
Ukuran Perusahaan & 90 & 8215481 & 5160785857 & 898641147,41 & 1576877137,371 \\
Nilai tukar & 90 & 9724,310 & 10557,285 & 10145,68361 & 381,127839 \\
Kupon & 90 & 6,75 & 11,30 & 9,3646 & 1,16003 \\
Maturity & 90 & 2,0 & 10,0 & 4,911 & 2,1445 \\
Likuiditas Obligasi & 90 & 1,0 & 2,0 & 1,278 &, 4504 \\
Solvabilitas & 90 &, 39 & 11,40 & 4,3938 & 2,55622 \\
Rentabilitas & 90 &,- 02 &, 06 &, 0274 &, 01864 \\
Valid N (listwise) & 90 & & & & \\
\hline
\end{tabular}

Sumber : IBM SPSS 23 (data diolah, 2019)

\section{IV.HASIL DAN PEMBAHASAN}

Pada pengujian hipotesis pengujian uji parsial atau uji $\mathrm{t}$ dengan membandingkan $\mathrm{t}$ statistic dengan $\mathrm{t}$ table. Berikut adalah tabel dari uji parsial:

Tabel 3

Uji Signifikansi secara Parsial (Uji t)

Coefficientsa

\begin{tabular}{cccccc}
\hline & \multicolumn{2}{c}{$\begin{array}{c}\text { Unstandardized } \\
\text { Coefficients }\end{array}$} & $\begin{array}{c}\text { Standardized } \\
\text { Coefficients }\end{array}$ & T & Sig. \\
\cline { 2 - 3 } & B & Std. Error & Beta & & \\
(Constant) & 5,200 & 1,259 & & 4,130 &, 000 \\
Suku Bunga &,- 052 &, 050 &,- 046 & $-1,036$ &, 303 \\
Rating &, 002 &, 047 &, 002 &, 041 &, 967 \\
Ukuran Perusahaan & $1,042 \mathrm{E}-11$ &, 000 &, 014 &, 347 &, 729 \\
Nilai tukar & $-3,244 \mathrm{E}-5$ &, 000 &,- 010 &,- 343 &, 733 \\
Kupon &, 961 &, 059 &, 918 & 16,257 &, 000 \\
Maturity &,- 305 &, 017 &,- 538 & $-17,810$ &, 000 \\
Likuiditas Obligasi &,- 148 &, 081 &,- 055 & $-1,837$ &, 070 \\
Solvabilitas &,- 003 &, 014 &,- 007 &,- 228 &, 820 \\
Rentabilitas & $-4,328$ & 2,176 &,- 066 & $-1,989$ &, 050 \\
\hline
\end{tabular}

Sumber : Data sekunder yang diolah 
Berdasarkan tabel 3 suku bunga menunjukkan nilai t statistik sebesar $-1,036$, itu berarti bahwa nilai $\mathrm{t}$ statistik $(-1,036)<\mathrm{t}$ tabel $(-1,99085)$ dengan tingkat signifikansi $0,303>0,05$, yang artinya hipotesis 1 ditolak. Hal ini dibuktikan dengan adanya obligasi berkelanjutan III Adira Finance Tahap III Tahun 2016 Seri B yang memberikan yield obligasi sebesar $12,77 \%$ dan obligasi berkelanjutan III Adira Finance Tahap IV Tahun 2016 Seri B memberikan yield obligasi sebesar $11,99 \%$ dengan tingkat suku bunga pada tahun 2016 sebesar 4,75\%. Berdasarkan data penelitian tersebut membuktikan bahwa, naik turunnya tingkat suku bunga tidak mempengaruhi pada besarnya yield obligasi.

Analisis peringkat obligasi terhadap yield obligasi pada perusahaan korporasi yang terdaftar di Bursa Efek Indonesia (BEI) tahun 2015-2017 menunjukkan bahwa nilai $\mathrm{t}$ statistik sebesar 0,041 , itu berarti bahwa nilai $t$ statistik $(0,041)<\mathrm{t}$ tabel $(1,99085)$ dengan tingkat signifikansi 0,967 $>0,05$, yang artinya hipotesis ditolak. Hal ini dibuktikan dengan adanya obligasi berkelanjutan II Indomobil Finance Tahap I Tahun 2015 Seri C yang memberikan yield obligasi sebesar 12,84\% dan obligasi berkelanjutan II Indomobil Finance Tahap II Tahun 2015 Seri C memberikan yield obligasi sebesar $13,62 \%$ dengan tingkat peringkat obligasi A (2). Berdasarkan data penelitian tersebut membuktikan bahwa, naik turunnya peringkat obligasi tidak mempengaruhi pada besarnya yield obligasi.

Ukuran perusahaan menunjukkan nilai $t$ statistik sebesar 0,347 , itu berarti bahwa nilai $\mathrm{t}$ statistik $(0,347)<\mathrm{t}$ tabel $(1,99085)$ dengan tingkat signifikansi $0,729>0,05$, yang artinya hipotesis ditolak. Hal ini dibuktikan dengan adanya obligasi berkelanjutan I Indosat Tahap II Tahun 2015 Seri C yang memberikan yield obligasi sebesar $12,15 \%$ dan obligasi berkelanjutan I Indosat Tahap III Tahun 2015 Seri C memberikan yield obligasi sebesar 12,28\% dengan ukuran perusahaan sebesar 55.388.517. Berdasarkan data penelitian tersebut membuktikan bahwa, besar kecilnya ukuran perusahaan tidak mempengaruhi pada besarnya yield obligasi.

Nilai tukar terhadap yield obligasi menunjukkan nilai t statistik sebesar $-1,343$, itu berarti bahwa nilai $\mathrm{t}$ statistik $(-1,343)<\mathrm{t}$ tabel $(-$ 1,99085) dengan tingkat signifikansi 0,733 > 0,05 , yang artinya hipotesis ditolak. Hasil penelitian menunjukkan bahwa tidak terdapat pengaruh nilai tukar terhadap yield obligasi. Hal ini mempunyai arti bahwa naik turunnya peringkat obligasi tidak mempengaruhi pada besarnya yield obligasi.

Analisis kupon terhadap yield obligasi pada perusahaan korporasi yang terdaftar di Bursa Efek Indonesia (BEI) tahun 2015-2017, meunjukkan bahwa nilai t statistik sebesar 16,257 , itu berarti bahwa nilai $t$ statistik $(16,257)>t$ tabel $(1,99085)$ dengan tingkat signifikansi $0,000<0,05$ atau terdapat pengaruh positif. Hal ini dibuktikan dengan adanya obligasi berkelanjutan II Waskita Karya Tahap I Tahun 2016 yang memberikan yield obligasi sebesar $12,51 \%$ dengan kupon obligasi sebesar 9,25\% dan obligasi berkelanjutan II Waskita Karya Tahap III Tahun 2017 Seri A memberikan yield obligasi sebesar $11,73 \%$ dengan kupon obligasi sebesar $8,50 \%$. Berdasarkan data penelitian tersebut membuktikan bahwa, naik turunnya kupon obligasi berpengaruh pada besarnya yield obligasi, semakin besar kupon yang ditawarkan semakin besar pula yield obligasi yang diberikan.

Adapun analisis maturity berpengaruh terhadap yield obligasi pada perusahaan korporasi yang terdaftar di Bursa Efek Indonesia (BEI) tahun 2015-2017, menunjukkan bahwa nilai $t$ statistik sebesar $-17,810$, itu berarti bahwa nilai t statistik $(-17,810)>\mathrm{t}$ tabel $(-1,99085)$ dengan tingkat signifikansi $0,000<0,05$ atau ada pengaruh negatif dan signifikan. Hal ini dibuktikan dengan adanya obligasi berkelanjutan II Bank BTN Tahap I Tahun 2015 Seri C yang memberikan yield obligasi sebesar $11,66 \%$ dengan maturity obligasi 7 tahun dan obligasi berkelanjutan III Bank BTN Tahap I Tahun 2017 Seri D memberikan yield obligasi sebesar $10,14 \%$ dengan maturity obligasi 10 tahun. Berdasarkan data penelitian tersebut membuktikan bahwa, panjang pendeknya waktu jatuh tempo suatu obligasi mempengaruhi besarnya yield obligasi yang diberikan.

Analisis likuiditas obligasi terhadap yield obligasi pada perusahaan korporasi yang terdaftar di Bursa Efek Indonesia (BEI) tahun 2015-2017, menunjukkan bahwa nilai t statistik sebesar 1,837 , itu berarti bahwa nilai t statistik $(-1,837)<$ $\mathrm{t}$ tabel $(-1,99085)$ dengan tingkat signifikansi $0,070>0,05$, yang artinya hipotesis ditolak atau tidak ada pengaruh. Hal ini dibuktikan dengan adanya obligasi berkelanjutan II Medco Energi Internasional Tahap IV Tahun 2017 Seri B yang 
memberikan yield obligasi sebesar 13,50\% dan obligasi berkelanjutan II Medco Energi Internasional Tahap V Tahun 2017 Seri B memberikan yield obligasi sebesar $14,13 \%$ dengan likuiditas obligasi 1 tahun. Berdasarkan data penelitian tersebut membuktikan bahwa, seberapa sering obligasi diperjual belikan pada Bursa Efek Indonesia (BEI) dalam 1 tahun tidak mempengaruhi pada besarnya yield obligasi.

Analisis solvabilitas terhadap yield obligasi pada perusahaan korporasi yang terdaftar di Bursa Efek Indonesia (BEI) tahun 2015-2017, menunjukkan nilai t statistik sebesar $-0,0228$, itu berarti bahwa nilai $\mathrm{t}$ statistik $(-0,228)<\mathrm{t}$ tabel $(-$ 1,99085) dengan tingkat signifikansi $0,820>$ 0,05 , yang artinya hipotesis ditolak atau tidak ada pengaruh. Hal ini dibuktikan dengan adanya obligasi berkelanjutan III Sarana Multygriya Finansial Tahap VII Tahun 2016 Seri B yang memberikan yield obligasi sebesar $11,62 \%$ dan obligasi berkelanjutan IV Sarana Multygriya Finansial Tahap I Tahun 2017 Seri B memberikan yield obligasi sebesar 10,99\% dengan solvabilitas sebesar $0,93 \%$. Berdasarkan data penelitian tersebut membuktikan bahwa, besarnya aset perusahaan yang dibiayai dengan utang tidak mempengaruhi pada besarnya yield obligasi.

Sedangkan analisis rentabilitas terhadap yield obligasi pada perusahaan korporasi yang terdaftar di Bursa Efek Indonesia (BEI) tahun 2015-2017, menunjukkan bahwa nilai t statistik sebesar 1,989 , itu berarti bahwa nilai t statistik $(-1,989)<$ $\mathrm{t}$ tabel $(-1,99085)$ dengan tingkat signifikansi $0,50>0,05$, yang artinya hipotesis ditolak atau tidak ada pengaruh. Hal ini dibuktikan dengan adanya obligasi berkelanjutan II Pegadaian Tahap III Tahun 2016 Seri C yang memberikan yield obligasi sebesar $11,62 \%$ dan obligasi berkelanjutan I Pegadaian Tahap I Tahun 2017 Seri C memberikan yield obligasi sebesar 9,75\% dengan rentabilitas sebesar $0,01 \%$. Berdasarkan data penelitian tersebut membuktikan bahwa, besarnya profitabilitas perusahaan tidak mempengaruhi pada besarnya yield obligasi.

\section{SIMPULAN}

Berdasarkan analisis data dan pengujian hipotesis serta pembahan atas 90 sampel dari perusahaan korporasi yang mengeluarkan obligasi yang terdaftar pada Bursa Efek Indonesia (BEI) tahun 2015-2017 menunjukkan bahwa suku bunga, peringkat obligasi, ukuran perusahaan, nilai tukar, likuiditas obligasi, solvabilitas, dan rentabilitas tidak berpengaruh terhadap yield obligasi. Sedangkan kupon obligasi berpengaruh positif signifikan terhadap yield obligasi, dan maturity obligasi berpengaruh negatif signifikan terhadap yield obligasi. Penelitian selanjutnya sebaiknya menambahkan variabel lain terkait dengan faktor-faktor yang mempengaruhi yield obligasi dan memperpanjang tahun penelitian.

\section{DAFTAR PUSTAKA}

Aisah, S. H. (2014). Analisis Faktor-faktor yang Mempengaruhi Yield Obligasi Korporasi. SKRIPSI, 36.

Andrian, N. (2011). Analisis Faktor- Faktor Yang Mempengaruhi Peringkat Obligasi Pada Perusahaan Manufaktur Yang Terdaftar Di Bursa Efek Indonesia . SKRIPSI, 56.

Ang, R. (1997). Pasar Modal Indonesia. Jakarta: Mediasoft.

Desnitasari, I. (2013). Pengaruh Tingkat Suku Bunga, Peringkat Obligasi, Ukuran Perusahaan Dan Debt To Equity Ratio Terhadap Yield To Maturity Obligasi Korporasi Yang Terdaftar Di Bursa Efek Indonesia Periode 2010-2012. Information, Contemporary Accounting Research, 3.

Fahrizqi, A. (2010). Faktor-Faktor Fundamental, Mekanisme, Corporate Governance, Pengungkapan Coorporate \& Social Responsibility (CSR) Perusahaan Manufaktur Dan Sumber Daya Alam Di Indonesia. Dinamika Keuangan Dan Perbankkan, 38.

Ghozali, I. (2011). Aplikasi Analisis Multivariate dengan Program IBM SPSS 19. Semarang: Universitas Diponegoro.

Hartono, J. (2013). Teori Portofolio Dan Analisis Investasi. Yogyakarta: BPFE-YOGYAKARTA.

Hidayat, Q. A. (2016). Pengaruh Likuiditas, Jangka Waktu Jatuh Tempo, Dan Kupon obligasi Terhadap Harga Obligasi Perusahaan Yang Terdaftar Di Bursa Efek Indonesia. SKRIPSI, 19.

Houston, E. F. (2001). Manajemen Keuangan. Jakarta: Erlangga.

Husnan, S. (2005). Dasar-dasar Teori Portofolio dan Analisis Sekuritas. Yogyakarta: UPP STIM YKPN.

Husnan, S. (2005). Dasar-dasar Teori Portofolio dan Analisis Sekutitas . Yogyakarta: AMP YKPN.

Ibrahim, H. (2008). Pengaruh Tingkat Suku Bunga, Peringkat Obligasi, Ukuran. Tesis, 20.

Indarsih, N. (2013). Pengaruh Tingkat Suku Bunga Sbi, Rating, Likuiditas Dan Maturitas Terhadap Yield To Maturity Obligasi. Ilmu Manajemen, 5.

Indriantoro, B. S. (2000). Metodologi Penelitian Bisnis Untuk Akuntansi \& Manajemen. Yogyakarta: BPFEYogyakarta.

Kasmir. (2013). Analisis Laporan Keuangan. Jakarta: PT Raja Grafindo Persada.

Kurniasari, C. D. (2016). Pengaruh Nilai Kurs, Rentabilitas, dan Tingkat terhadap Yield Obligasi Pada Perusahaan Manufaktur Yang Terdaftar di BEI. SKRIPSI, 6.

Muhardi, D. d. (2013). Analisis Laporan Keuangan Proyeksi Dan Valusi Saham. Jakarta: Salemba Empat. 
Muhardi, W. d. (2013). Analisis Laporan Keuangan Proyeksi dan Valuasi Saham. Jakarta: Salemba Empat.

Nasuha, R. (2018, Desember Jum'at). Analisis Metode Capital Asset Pricing Model Dalam Upaya Pengambilan Keputusan Terhadap Investasi Saham. 21, hal. 1.

Nuary, M. (2015). Analisis Faktor-Faktor Yang Mempengaruhi Yield Obligasi Korporasi, 1.

Nuary, M. (2015). Analisis Faktor-Faktor Yang Mempengaruhi Yield Obligasi Korporasi Pada Perusahaan Penerbit Obligasi Di Bursa Efek Indonesia. SKRIPSI, 1.

Oky Oktavian, H. d. (2015). Pengaruh Tingkat Inflasi, Debt To Equity Ratio, Likuiditas Obligasi Dan Rating Obligasi Terhadap Yield Obligasi Kororasi Yang Terdaftar Di Bursa Efek Indonesia (BEI) Tahun 2009 - 2012Pengaruh Tingkat Inflasi, Debt To Equity Ratio, Likuiditas Obligasi Dan. JOM FEKON, 1.

Paramita, L. N. (2018). Pengaruh Tingkat Suku Bunga, Inflasi, Debt To Equity Ratio,Dan Ukuran Perusahaan Terhadap Yield Obligasi Pada Perusahaan Yang Terdaftar Di Bursa Efek Indonesia Tahun 2010-2016. Manajemen, 8.

Permana, N. S. (2017). Pengaruh Peringkat, Likuiditas, Kupon Dan Maturitas Terhadap Yield Obligasi Pada Bursa Efek Indonesia (Bei) Periode 2013-2014. Muara Ilmu Ekonomi Dan Bisnis, 7.

Prasetiono, T. A. (2014). Analisis Faktor-Faktor Yang Mempengaruhi Yield Obligasi Konvensional Di Indonesia. Studi Manajemen dan Organisasi, 3.

Prihadi, T. (2010). Analisis Laporan Keuangan: Teori dan Aplikasi. Jakarta: PPM.

Ross, w. d. (2009). Pengantar Keuangan Perusahaan Corporate Finance Fundamentals. Jakarta: Salemba Empat.

Rozali, M. S. (2017). Pengaruh Likuiditas Obligasi, Maturity, Dan Inflasi Terhadap Yield To Maturity Obligasi Negara. Skripsi, 43.

Samsul, M. (2002). Pasar Modal dan Manajemen Portofolio. Jakarta: Erlangga.

Sanusi, A. (2013). Metodologi Penelitian Bisnis. Jakarta: Salemba Empat.

Saputra, S. d. (2013). Analisis Faktor-Faktor Yang Mempengaruhi Yield Obligasi Konvensional Di Indonesia. Skripsi, 53.

Saputra, T. A. (2013). Analisis Faktor- Faktor Yang Mempengaruhi Yield Obligasi Konvensional Di Indonesia. Skripsi, 48.

Sudjarni, N. K. (2016). Pengaruh Likuiditas Obligasi, Waktu Jatuh Tempo, Dan Kupon Obligasi Terhadap Perubahan Harga Obligasi Korporasi Berperingkat. E -Jurnal Manajemen Unud, 15.

Sugianto, D. (2018, November Jum'at). Pecahkan Rekor, BEI Jaring 200.000 Investor Baru Tahun Ini. Dipetik November Selasa, 2018, dari Detik.com: https:// finance.detik.com/bursa-dan-valas/d-4305276/ pecahkan-rekor-bei-jaring-200000-investor-barutahun-ini? ga $=2.179556451 .611919168 .1542767268$ $-621284568.1542090209$

Sugiono. (2014). Metode Penelitian Kuantitatif, Kualitatif dan R\& D. Bandung: Alfabeta.

Suhardi, P. d. (2003). Statistik Untuk Ekonomi Dan Keuangan Modern Jilid 1. Jakarta: Salemba Empat.
Sukirno, S. (2003). Pengantar Teori Makro Ekonomi. Dalam S. Sukirno, SE. M.S. Sc. (hal. 16). Jakarta: PT Raja Grafindo Prasada.

Sunariyah. (2011). Pengantar Pengetahuan Pasar Modal. Yogyakarta: UPP STIM YKPN.

Susilo, B. (2009). Pasar Modal. Yogyakarta: UPP STIM YKPN Yogyakarta.

Tandelilin, E. (2010). Portofolio dan Investasi. Yogyakarta: Kanisius.

Winarwo, W. W. (2015). Analisis Ekonometrika dan Statistika dengan Eviews Edisi 4. Yogyakarta: UPP STIM YKPN.

Yuniar Laeli Nur Faizah, E. S. (2013). Pengaruh Profitabilitas, Likuiditas, Size Dan Leverage Perusahaan Terhadap Yield Obligasi Dengan Peringkat Obligasi Sebagai Variabel Intervening. Staf Pengajar Pada Jurusan Akuntansi FEB Universitas Jendral Soedirman, 5.

Zubir, Z. (2012). Portofolio Obligasi. Jakarta: Salemba Empat. 